\title{
Local Government Capacity for Solid Waste Collection in Local Markets in Tanzania
}

\author{
Stella Malangalila Kinemo \\ Senior Lecturer $(\mathrm{PhD})$, Mzumbe University, Tanzania \\ School of Public Administration and Management \\ E-mail: smkinemo@mzumbe.ac.tz
}

Received: Nov. 11, 2019 Accepted: Dec. 11, 2019 Online published: Dec. 24, 2019

doi:10.5296/jpag.v9i4.16125 URL: https://doi.org/10.5296/jpag.v9i4.16125

\begin{abstract}
Solid waste collection is one of the roles of municipal councils in Tanzania stipulated by the local government Act of 1982. This study empirically examined the capacity of Morogoro Municipal Council in collecting solid waste generated from the two market centers of Mawenzi and Manzese. The study employed case study design and mixed research approaches of qualitative and quantitative. The data collection methods were in-depth interviews and questionnaire. The data obtained in this study were subjected to interpretative and content analysis for qualitative data and descriptive statistics for quantitative data. Findings revealed that the most dominant type of waste generated in the two markets were the biodegradable wastes generated from natural products such as vegetables, fruits and food remains in general. More findings show that the process of solid waste management needed the resources of different types including financial resources, physical resources and human resources. It was found that Morogoro Municipal Council had inadequate resources to manage the amounts of the generated wastes in the two markets. To improve capacity of collecting solid waste in the two markets the study recommends increasing number of staff, vehicles and containers for waste collection, increase budget for solid waste collection and collect the waste frequently according to the accumulation of waste.
\end{abstract}

Keywords: solid waste, local government, capacity

\section{Introduction}

Today the issue of solid waste management in urban areas is increasingly becoming a global issue. Some scholars have classified sources of solid waste to be residential, institutional and commercial areas (Palanivel and Sulaiman, 2014). They emphasize that for effectiveness of solid waste management control there is a need of categorizing wastes. Literature indicates 
that many countries have adopted public-private partnership (PPP) as an alternative for municipal solid waste management at very low cost (Lohri et al., 2013). However, things are different in the developing countries where due to economic problems and extreme poverty, solid waste management is not sufficiently observed. In African countries there is huge amount of solid waste which affects the environment. In Tanzania, solid waste generation and management in municipal areas is critical with challenges in environmental sanitation problems. Some studies conducted in Tanzania show that sources, types and composition of solid wastes differ from place to place (Ntakamulenga, 2012; Maziku, 2014; Mnyanyi, 2014).

According to section 55 (g) of the Local Government Act 1982 and the Environmental Management Act of 2004 of Tanzania, solid waste management is one of the roles of all urban authorities in Tanzania. Local authorities are required to collect all solid waste from public and private sectors, provide and maintain public containers for the proper deposit and management of Solid Waste while waiting for the proper disposal (Tanzania Local Government Act of 1982).

However, in Tanzania, solid waste management has become a threat to human health and environmental degradation especially in urban areas. A study conducted by Mollel (2016) reported big volumes of solid wastes being produced in the Morogoro Municipality everyday (over 200 tons). Despite the fact that Morogoro Municipal Council has put effort to collect solid waste implementation remains a consistent problem. It has been observed that in Morogoro waste management specifically on solid waste collection is inefficient. In Morogoro municipality the question of collecting and disposing solid waste is problematic and studies have shown that the municipality can only collect and dispose $35 \%$ of the waste (Mollel, 2016). Basing on this background the study examined the capacity of Morogoro Municipality in collecting solid waste for the Mawenzi Market and Manzese Market.

\section{Literature Review}

\subsection{Generation of Solid Waste}

Solid wastes are generated by domestic, commercial, industrial, healthcare, agriculture, mineral extraction activities (Maziku, 2014). Lagbas (2015) has categorized wastes according to human and animal activities that are no longer needed. According to Tchobanoglous et al, (1993) solid waste generation refers to all materials which are produced and are no longer in use waiting for disposal. He clarified by providing sources of solid waste from residents, places where food is sold, industrial areas and local markets. The focus of this study was on the solid waste from local markets of municipalities. As provided in the literature Tchobanoglous et al. (1993) solid waste management includes "the control of generation, storage, collection, transfer and transport, processing, and disposal of solid wastes". Solid waste management involves different systems, activities and actions required to manage waste from its inception to its final disposal. This includes amongst other things, collection, transport, treatment and disposal of waste together with monitoring and regulation (Okpala 1999). Rayes (2004) emphasizes that waste management also involves treatment and final disposal. In this study only one aspect of solid waste management which is collection of waste from local markets was studied. 


\subsection{Empirical Studies on Solid Waste Collection}

Joshi and Ahmed (2016) conducted a study on "Status and challenges of municipal solid waste management in India". He found out that the biodegradable waste was generated in high quantity. Babayemi and Dauda (2009) in the study on solid waste generation, categories and disposal options identified that sources of solid waste generation were commercial centres, industries, households, agricultural and education establishments. However he did not consider solid waste from local markets of municipalities. Rahman and Sinthia (2013) conducted a study on "Solid waste management strategy and improvement of existing scenario based on market waste". The study identified market solid wastes such food wastes, paper, cardboards, plastics, textiles, rubber, leather, wood, glass, and ferrous metals. The findings confirm that there is generation of solid waste in local markets which need attention by the municipals. The study by Rana, Ganguly and Gupta (2017) on "Resources and their influence to solid waste management in India" revealed that towns of India were experiencing insufficient resources for solid waste management including lack of vehicles and trained workforce. The study by Babayemi and Dauda (2009) in Nigeria revealed that lack of funding and laxity in enforcement of sanitation laws affected waste management. Mlozi (2011) conducted a study on "The extent to which the community participates in solid waste management in Mbeya region in Tanzania" found that the Mbeya City Council could only collect $44 \%$ of the generated solid waste. One of the problems leading to poor waste management was lack of collection and storage facilities. Results from the empirical studies on solid waste management, has shown that there are problems in collecting solid waste in different countries. So far no study has been done to assess the capacity of the Morogoro Municipal Council to collect Solid Waste in local markets.

\section{Methodology}

\subsection{Area of the Study}

A descriptive case study design was used to collect data from two local markets in Tanzania. This paper draws from empirical study conducted in Morogoro Municipal Council (MMC) located in Tanzania. The municipality has two local markets which are Mawenzi Market and Manzese Market. The two markets were selected as areas of the study since they were the only markets in the municipality and they generated some substantial amount of solid waste about 200 metric tons (Mollel, 2016).

\subsection{Sample Size and Sampling Techniques}

In this study the population consisted of all business men and women (vendors) in the markets of Mawenzi and Manzese, market officials and the officials from the Environment Conservation Department in Morogoro Municipal Council. The total sample of 125 respondents was used in the study of which 120 were business vendors, two Community Health Officers of Morogoro Municipality, one Municipal Health Officer and two chairpersons of each market. Purposive sampling was used in selecting the two markets and market officers. Purposive sampling was also used in selecting key informants who were Municipal Health Officer and Community Health officials. The key informants were selected 
because they had required information on waste collection in the markets. The study employed simple random sampling to sample the business vendors who were selected from the list provided by Morogoro Municipal Council.

\subsection{Data Collection and Analysis}

A questionnaire was administered to 120 business vendors from the two market centers. The respondents were asked to fill the questionnaires that were distributed to them with the assistance of enumerators. The questionnaire composed of both open and closed ended questions in order to generate the required information. The study used interview method to elicit responses from the Municipal Community Health Officer, market community health officials and market chairpersons. The interviews were conducted to the key informants with the purpose of getting information on waste management practices. Direct observation was used to complement respondents' responses on the availability of waste facilities in the market centers. Qualitative and quantitative data were analyzed using content analysis and descriptive analysis respectively. The descriptive statistical analysis involves the use of percentages and frequencies. Content analysis was done by interpreting and describing meaningfully the themes which emerged during interview of respondents.

\section{Findings and Discussion}

\subsection{Types of Solid Waste Generated at the Two Markets Centres}

Respondents were asked to identify the type of solid waste which was generated in the two markets. It was found that the solid wastes included biodegradable wastes $(53.3 \%)$; recyclable (30\%) and composite (16.7\%). Konya et al. (2013) defined bio-degradable wastes as those wastes that can be degraded by bacteria fungi and include food wastes, green wastes, card boards, and paper. The findings indicate that most generated type of solid waste in the two markets were biodegradable waste. This is due to the nature of the products being solid in the markets. Most of the solid wastes were vegetables, food remains, spoiled fruits and paper waste. Similar results were reported by Mgimba and Sanga (2016) in a study conducted in Mbeya city, Tanzania and found that the dominant type of waste generated from domestic and education institutions was organic wastes that consisted of degradable wastes (57\%). The findings imply that Morogoro Municipal Council has a role to play in collecting vegetables, food remains, spoiled fruits and paper waste as stipulated in section 55 (g) of the Local Government Act 1982

\subsection{Availability of Resources for Waste Collection}

This section investigated whether MMC had the capacity to collect solid waste in terms of physical resources, human resources and financial resources. Responses were measured using Likert scale ranging from adequate, not adequate and somehow adequate. In other questions respondents were required to respond yes or no.

\subsubsection{Availability of Physical Resources}

Physical resources were measured by the availability of bins for waste collection; vehicles for waste transportation and the distance of the disposing from the market centre. During 
physical observation of the situation of the two markets, it was found out that the markets had insufficient physical resources and the uncollected wastes were scattered and spread all-over the surroundings of both markets. Furthermore, it was revealed that the waste collection buckets, vehicles for waste transportation, dustbins, bags and containers at both Manzese and Mawenzi were too few to be able to cope with the generated wastes. The scattering of waste can result to health problems to the communities surrounding the markets. The findings support findings of Mlozi (2011) who argued that some of the urban local authorities can collect waste led than $50 \%$.

\section{(a) Adequacy of municipal buckets}

Respondents were asked whether municipal containers for solid waste collection were adequate. Majority $(67.5 \%)$ of the respondents indicated that the municipal containers were not adequate. However, some respondents said they were somehow adequate $(25.0 \%)$ while a few $(7.5 \%)$ of the respondents said that the municipality buckets were adequate. Despite the fact that some respondents responded that municipality buckets were adequate in reality a lot of waste was not collected and left scattered around the markets. This implies that MCC had no capacity to collect solid waste at the required time. It was observed that there was only one container for waste collection at Manzese Market and Mawenzi had two. However, these three containers were not adequate compared to the generated wastes. The generated wastes especially in Mawenzi Market was far much higher compared to the number of times the wastes were transported to disposition places, thus rendering the capacity of the containers inadequate. The findings confirm that there is a miss-match between the generated waste and the capacity to dispose the waste by the MCC. Similar results were reported by Rana et al. (2017) in a study conducted in India.

\section{(b) Sufficiency of vehicles}

Respondents were asked whether there were adequate number of vehicles for collection of solid waste from the markets to the disposal point.. The findings show that majority $(77.5 \%)$ of the respondents reported that vehicles were not adequate while $18.0 \%$ of the respondents showed that vehicles were adequate. Only $7.5 \%$ of the respondents showed that vehicles were somehow adequate. These findings clearly show that non-availability of vehicles is an impediment to solid waste management at the Municipal Council. Similar findings were reported by Rana et al., (2017) in a study conducted in India found that non-availability of vehicles were the problem in effective solid waste management. Vehicles are very important in waste transportation to the disposition places. When the vehicles are inadequate the wastes accumulate and can cause health problems.

(c) Adequacy of dustbins and plastic bags for waste collection

Respondents were asked on the adequacy of dustbins and plastic bags for waste collection at the two markets. The results show that $33.3 \%$ of the respondents indicated that physical dustbins and bags were adequate; while $45.0 \%$ of the respondents showed that dustbins and bags were not adequate. Only $7.5 \%$ of the respondents showed that the dustbins and plastic bags where somehow sufficient. During discussions with the vendors at the Mawenzi market 
centre, the vendors revealed that sometimes they were using their own collecting bags and later they empty the waste into the Municipal bins. The vendors complained that the Municipal waste collectors did not return the bags to vendors. From financial point of view, many respondents complained about this practice by the Municipal waste collectors. At Manzese market, the situation was different. The business vendors were responsible for collecting the waste and empty them into the municipal bins. In this case, they could re-use their collection bags. This finding implies that the MCC has failed to provide dustbins to business vendors for waste collection.

\subsubsection{Availability of Human Resources}

Respondents were asked whether MCC has adequate manpower for solid waste collection in the two markets. The findings show that majority $(51.7 \%)$ of the respondents indicated that manpower was not adequate; while $33.3 \%$ of the respondents reported that manpower for waste collection were somehow adequate. However, $15.0 \%$ of the respondents indicated that the manpower was adequate. During discussions with the market administration, it was revealed that in Mawenzi Market there were ten people who were tasked by the MCC to deal with waste collection. However, this number was reported to be too small and therefore inadequate to collect the wastes from the whole market. The market officials argued that due to the small number of manpower in Mawenzi Market, waste collection was done once per day and the collection was done in the morning only.

During the interviews with the market officials it was revealed that two different systems operated at the two market centres. At Mawezi, the Municipal Council employed individuals to collect the wastes. At Manzese market, the vendors were responsible for collecting the wastes from their premises. The business vendors have twofold roles in solid waste management. They participate fully in waste collection by having their own simple tools where they collect garbage before they are emptied into the big municipal bins. They are also obliged to make their monthly contributions to facilitate waste collection.

For the case of Manzese Market, the business vendors were responsible for waste collection. It was found that it was upon the individual vendor to either employ someone to collect the wastes or to do themselves. This implies that it is likely that waste collection in Manzese Market was more effective than in Mawenzi. It is also likely for the waste collectors in Manzese to be more committed than those in Mawenzi because the vendors themselves feel the sense of ownership because they participate directly in cleanliness and collection of the accumulated wastes. However, it was found that there were informal waste collectors especially those who were collecting used plastic bottles and scrapers for selling. These self-employed individuals collected used plastic bottles and sold them elsewhere.

\subsubsection{Availability of Financial Resources}

The financial resource was measured by the overall budget of the local government to ensure waste management in the two market centers. The financial resources available to the two markets are from MMC and contributions from the vendors. The vendors pay cash TSh. 10,000/- per month as their contribution. However, the Local Government provides its 
contribution not in monetary form but in terms of facilities/working gear such as brooms, coats, wheel barrows, gumboots, hoes, racks and gloves. Interview with key informants revealed that the budget allocated to waste collection was inadequate. Only $7.5 \%$ of the respondents indicated that the budget allocated to waste collection in the markets was adequate.

During discussions with the Municipal Health officer, it was made clear that there were delays in the procurement process of the working gears and sometimes the demand was not met. As a consequence, many workers involved in waste collection did not get the required tools and protection gears. In some cases they were forced to collect the waste with their bare hands without any protection. Similar findings were reported by Babayemi and Dauda (2009) in a study undertaken in Nigeria where they found that funding was a key setback to solid waste management. This is an indication that waste collection at MCC is not given priority.

\section{Conclusion and Recommendations}

This study aimed to examine the capacity of Morogoro Municipal Council in collecting solid waste in local markets. The study focused on human resource capacity, financial resource capacity and physical resource capacity. The results of the study have revealed that the MCC has no capacity to collect all types of waste in the markets. The study found out that all of the mentioned resources were available but they were inadequate to meet the amounts of the generated wastes in the two markets. It was found that waste collection facilities were few and this situation calls for funding. There is an indication that budgeting for waste collection is not given priority by the MMC. It is recommended that the MCC should take deliberate efforts to increase number of skills and staff, increase number of containers for waste collection, increase budget, collect waste frequently according to the accumulation of waste and promote private and public participation in waste collection and disposal.

\section{References}

Babayemi, J. O., \& Dauda, K. T. (2009). Evaluation of solid waste generation, categories and disposal options in developing countries: A case study of Nigeria. Journal of applied science in environment management, 13(3), 83-88. https://doi.org/10.4314/jasem.v13i3.55370

Joshi, R., \& Ahmed, S. (2016). Status and challenges of municipal solid waste management in India. A review Cogent Environmental Science, 2(11), 1-18. https://doi.org/10.1080/23311843.2016.1139434

Konya, R. S., Zitte, L. F., \& Ugwulor, Q. N. (2013). Characterization of waste and their recycling potentials: A case of East-Road Port Harcourt. Journal of Applied Sciences and Environmental Management, 17(2), 233-238. https://doi.org/10.4314/jasem.v17i2.7

Lohri, C. R., Camenzind, E. J., \& Zurbrugg, C. (2013). Financial sustainability in municipal solid waste management-Costs and revenues in Bahir Dar, Ethiopia. Waste Management, 34, 542-552. https://doi.org/10.1016/j.wasman.2013.10.014

Labgas, A. G. U. (2015). The Theoretical Underpinnings of the solid waste management practices: A proposed blueprint towards government action. European Scientific Journal, 
11(23), 343-355.

Maziku, J. D. (2014). Improving Solid Waste Management in the Dar-es-Salaam Coastal Belt, Tanzania. Unpublished Bachelor Thesis of Novia University of Applied Sciences.

Mnyanyi, N. B. (2014). Assessment of Solid Waste Management in Kinondoni Municipality. A Dissertation Submitted in Fulfilment of the Requirements for the Degree of Masters of Environmental Studies (Science) of Open University of Tanzania.

Mlozi, M. N. (2011). Assessment of community participation in solid waste management: The case of Mbeya City Council in Tanzania. A Dissertation Submitted in Fulfilment of the Requirements for the Degree of Masters of oArts in Rural Development of Sokoine University of Agriculture.

Mollel, E. L. (2016). Economic analysis of solid waste management options in Morogoro Municipality, Tanzania. A Dissertation Submitted in Fulfilment of the Requirements for the Award of Degree of Masters of Science in Environmental and Natural Science Economies of Sokoine University of Agriculture.

Mondol, E. F., Hassan, R., Alam, S., Rahman, A., \& Sinthia, T. T. (2013). Solid Waste Management Strategy \& Improvement of Existing Scenario Based on Market Waste. Global Journal of Researches in Engineering Civil and Structural Engineering, 13(4), 1-13.

Mgimba, C., \& Sanga, A. (2016). Municipal solid waste composition characterization for sustainable management systems in Mbeya. International Journal of Science, Environment and Technology, 5, 47-58.

Ntakamulenga, R. (2012). The status of solid waste management in Tanzania. A Paper Presented During The Coastal East Africa Solid Waste Workshop Held In Flic En Flac, Mauritius.

Okpala, N. (1999). Changing perspectives of solid waste management in Anambra State. Journal of Environmental Studies, 2(1), 45-51.

Palanivel, T. M., \& Sulaiman, H. (2014). Generation and composition of municipal solid waste (MSW) in Muscat, Sultanate of Oman. Thenmozhi Murugaian Palanivel and Hameed Sulaiman / APCBEE Procedia, 10, 96-102. https://doi.org/10.1016/j.apcbee.2014.10.024

Rana, R., Ganguly, R., \& Gupta, A. K. (2017). Evaluation of solid waste management in satellite towns of Mohali and Panchkula in India. Journal of Solid Waste Technology and Management, 43(4), 280-294. https://doi.org/10.5276/JSWTM.2017.280

Tchobanoglous, G., Theisen, H., \& Vigil, S. (1993). Integrated solid waste: Engineering principles and management issues ( $2^{\text {nd }}$ ed.). McGraw-Hill: USA.

United Republic of Tanzania (1982). "The Local Government (urban Authorities) Act No. 8 of 1982 (revised 2000).” Dar-es-Salaam, Government Printer. 


\section{Copyright Disclaimer}

Copyright for this article is retained by the author(s), with first publication rights granted to the journal.

This is an open-access article distributed under the terms and conditions of the Creative Commons Attribution license (http://creativecommons.org/licenses/by/4.0/). 